\title{
Jaká doba, takové divadlo: k povzdechu Wolfganga Spitzbardta nad mimésis v dnešním divadle, komentář prizmatem Aristotelovy Poetiky
}

\author{
Alena Sarkissian
}

SPITZBARDT, Wolfgang. Divadlo v krizi (?) aneb Pokus o mimesis. Brno: Nakladatelství Janáčkovy akademie múzických umění, 2019. $70 \mathrm{~s}$.

Útlý svazek z řady Úvahy a názory, vydávaný JAMU, reflektuje, podobně jako ostatní tituly série, performativní umění, v tomto př́ípadě divadlo. Činí tak v širších společenských a kulturních souvislostech. Wolfgang Spitzbardt se snaží přijít na kloub proměně divadla, jak ji s nemalým znepokojením vnímá a touží pojmenovat. Jeho esej má tudíž velmi osobní ráz. Začíná působivým úvodem, kde popisuje své stýkání s divadlem od dětství, prožitého v NDR, po současnost, kdy působí nejen jako pedagog JAMU, ale i jako praktikující divadelník.

Při čtení jsem oscilovala mezi souhlasem a jistou rozmrzelostí: příčiny obojího hned objasním. Považuji tento dvojaký účinek Spitzbardtova textu za veskrze pozitivní věc: provokuje a nutí čtenáře, aby se přes nesouhlas přenesl a místa, jež považuje za problematická, pře- a doformuloval.

Po úvodu, který bych dokázala číst mnohem déle a v podrobnější podobě, protože je to vlastně mikroautobiografie autora s pozoruhodným životním osudem, následuje naopak velmi diskutabilní, nutně generalizující a místy proto zkreslující historická pasáž, ve které se autor pokouší doložit, že „v okcidentálním kontextu, a zřejmě nejen tam, je zrod divadla výsledkem společenské krize“ (19). Bohužel to autor ilustruje nejprve na případu řeckého divadla, jehož poznání se v posledních desetiletích velmi proměnilo (a Spitzbardt pojetí řeckého divadla čerpal z publikace z r. 1969, jiné zdroje necituje). Ač je teze, kterou chce doložit, pro řecké divadlo platná, dokládá ji jaksi mimoběžně s tím, co o řeckém divadle známe v roce 2020. Wolfgang Spitzbardt mluví o počátcích řeckého divadla v rituálu, kultu, magii a mystériích (20). To je dnes považováno za nedoložitelnou spekulaci, a proto ostatně ani nové příručky dějin řeckého divadla nehledají onen prapočátek a omezují se na popis nejstarších pramenů, písemných i archeologických, které by snad mohly s počátky divadla souviset, aniž to však tvrdí (srov. např. CSAPO a MILLER 2007). Velmi akutně se také tážu, jak lze přelom 6. a 5. století př. Kr., ze kterého pocházejí první známé prameny pro divadelní agón v Athénách, označovat za období „počínající dekadence řecké polis“ (takto na s. 20$){ }^{1}$

1 A také si hned odpovídám: text, na který se Wolfgang Spitzbardt odvolává, je zřejmě myšlenkově závislý na Nietzscheově Zrození tragédie z ducha hudby, který si periodizaci dějin divadla v závislosti na vývoji athénské polis přizpůsobuje tomu, jaké závěry chce pro své téma učinit. (Nicméně přesto jde o text, mám na mysli Zrození, který výstižně a takřka vizionářsky pojmenoval mnoho podstatných rysů řecké tragédie.) 
V posledních letech se navíc stále více badatelů snaží zkonstruovat hypotézu konkurenční k této tzv. „rituální“ verzi, tedy o vzniku divadla jako ryze umělého a uměleckého konstruktu, cíleně využívajícího ztělesňování a dočasné změny identity ke komunikaci s publikem. ${ }^{2}$ Jakkoli ale tuto krizi uchopuje Spitzbardt za konec, se kterým lze jen obtížně souhlasit bez výhrad, dotýká se skutečně důležitého rysu řeckého divadla, který nikdy nepřestane být aktuální: řecké divadlo vzniká z krize, pokud ji chápeme jako okamžik, kdy je třeba se rozhodovat a volit řešení. ${ }^{3}$ Objevuje se, pokud víme, poprvé v Athénách (kam ale bylo možná importováno z periferie) v kritické době, kdy athénská polis prochází mnoha reformami, které vyústí až v přerod Athén z tyranidy v demokratickou obec. A právě demokracie je nejen živnou půdou athénského divadla, ale také neustálým dialogem a diskusí o překonání krizí, hrozeb, nejistot. A tyto diskuse se vedou také prostřednictvím divadla. Divadlo, tragédie i komedie (o satyrské hře víme př́liš málo), zobrazuje krize a vhodné i méně vhodné, úspěšné i méně úspěšné způsoby jejich překonání. Tragédie i komedie se rodí na kritické hranici soužití individua (v řecké komunitě podružné hodnotě) a kolektivu (v řecké komunitě hlavní hodnota), ukazuje kritický střet starých a nových hodnot (snad nejnázorněji demonstrovaných v Orestei a neméně pů-

2 Více k tématu viz esej (TAPLIN 2020).

3 Ostatně etymologii tohoto slova na s. 19 také spíše zamlžil, nežli osvětlil, a vybral ze širokého sémantického pole slova, jak je to v řečtině běžné, možná zbytečně vyhrocené odstíny. Krínó je prostě soudím, rozhoduji, odděluji, vybírám. Odtud krisis jako zlomový okamžik, okamžik volby. Kritika pak není jen rozhodování o kvalitě, ale i „oddělování zrna od plev,“ vybírání toho, co stojí za to uchovat. sobivě třeba v Oidipu králi, ${ }^{4}$ byt’ takto lze číst veškeré řecké drama, včetně komedie). O tom, jak divadlo vzniká v kritické době řecké polis, ostatně píše ve svém základním eseji Jean-Pierre Vernant ${ }^{5}$ a ukazuje, že jen krize mohla zrodit tragédii (a potažmo celé divadlo), na mnohem jasnějším materiálu, nežli je domněnka o rituálu a mystériích.

Spitzbardt dále svou hypotézu dokládá židovským kontextem, jehož zobecnění nemohu posoudit, a proto se vyjádřím až ke Spitzbardtově exkurzu do středověku, v němž vývoj divadla líčí jako lineární a jaksi „souměrný“, přičemž navíc text Mastičkáře označuje za produkt společensko-náboženské krize 14. století. Obojí je značně zkreslující a dnes již dobře víme, že kontext provozování různých podob středověkých her byl složitější, spletitější a rozmanitější, než nám zavedené příručky ještě i ze 2. poloviny 20. století tvrdily. Nelze naopak s jistotou doložit, z jakého textového okolí pochází Mastičkář, ani v jakém prostoru (chrámovém? nebo na veřejném prostranství?) byl tento text, dochovaný ve dvou fragmentech, provozován.

Tento můj exkurz by mohl vypadat (a vypadá) jako mudrování teatrologa nad dílem autora, který přitom hned na počátku knihy jasně přizná, že teatrolog není. Myslím ale, že když na těchto tvrzeních zakládá své další úvahy o divadle, je nutno na jisté nesrovnalosti upozornit, a přinejmenším

4 Jako základní, a v mnoha ohledech dodnes nepřekonanou publikaci ke čtení dramatu Oidipús král skrze tenze, tedy krize v kultuře a společnosti Athén 5. století, uved'me (KNOX 1957). Kniha byla znovu vydána roku 1998 pod názvem Oedipus at Thebes: Sophocles' Tragic Hero and His Time.

5 (VERNANT 1992), původně vydáno jako "Tensions and Ambiguities in Greek Tragedy“ in Interpretation: Theory and Practice, Baltimore, 1969: 105-121. Vernant pak dokazuje tyto principy i ve svých dalších textech věnovaných řecké tragédii. 
v př́ípadě řeckého divadla také nabídnout hutnější materiál k doložení autorovy teze.

Ta v první části zní, že divadlo se rodí z krize, ve druhé, že v současné době divadlo společenskou krizi není schopné analyzovat, protože degeneruje. Přichází prý o svou mimetickou podstatu a mění se v cosi invalidního, sebestředného a bezcílného. Př́ćcinou je podle Spitzbardta jakási epidemie digitální demence, jež zploštuje lidské vnímání, v širším kontextu označuje za viníka krize i za šiřitele epidemie digitální demence liberální kapitalismus. Své tvrzení o digitální demenci dokládá Spitzbart velmi pečlivě, i pečlivěji, nežli si formát eseje žádá. Tvrzení o destruktivním efektu kapitalismu na lidstvo zůstávají v úrovni přesvědčení autora, ostatně nic jiného ani není možné. Autorovy nářky, jakkoli ten pojmenovává bezesporu významné faktory formující dnešní podobu světa, nesou jisté rysy odsudku mladých z úst starých, tak jak je známe z literatury od nejstarších dob.

Ano, Wolfgang Spitzbardt uvádí příklady jevištních performancí, které jej utvrdily v pocitu vytrácení divadelní esence, $m i$ mésis. Definici této esence se pak pokouší uchopit celým esejem, který končí jakýmsi manifestem ideálního divadla, ve kterém by se mimésis realizovala $\mathrm{v}$ plnosti. Má to ale své háčky.

Pojem mimésis sám autor chápe aristotelským způsobem, platónské pojetí pak výslovně staví na okraj (41-42). Mimésis tudíž pro něj není prostá imitace, ale jak sám říká, je to spís strukturální princip uměleckého výtvoru, v případě divadla pak použijme obrat „umělecké události“.

Kdybych překládala Poetiku, měla bych - jako všichni - s překladem slova mimésis potíž. Shodneme se asi, že imitace je naprosto nevhodný překlad, Francouzi volí často pojem reprezentace, kde je ale podle mne odstín pojmu nápodoba také př́tomen. Pro mě je ale, stejně jako do jisté míry pro Spitzbardta, důležitý onen aspekt mimésis, který z celé Poetiky vyplývá a který nazývám konstrukční (oproti rekonstrukční mimésis platónské). Aristotelés zná svobodného tvưrce, který tvoří nové a nemusí se nechat spoutat žádnou předlohou. Divák tedy často nemusí plně racionálně proniknout do těchto nových výtvorů, ale může zažít estetickou libost i pouhým vnímáním estetických harmonií a proporcí (ARISTOTELES, Poetika: 1448b). Prvek narace a ludičnosti, pro Spitzbardta tak důležitý v pojmu mimésis, je pro Aristotela příznakem mimésis tragické, ne však mimésis obecně, i Spitzbardt však samozřejmě myslí mimésis divadelní a jako další její rys zdůrazňuje dialogičnost, která z moderních inscenací mizí (a mizí podle něj i z nových dramatických textů).

Především je nutno upozornit, že jakkoli v celém eseji hovoří Spitzbardt o vytrácení mimetického aspektu z divadla, myslí ve skutečnosti vytrácení čehosi jiného. Jestliže mimésis chápe jako strukturální princip jakéhokoli uměleckého tvoření, tedy nejen divadelního nebo výtvarného umění (a v tomto smyslu cituje i Jana Motala, 40), pak musí být tento prvek přítomen v jakémkoli uměleckém výtvoru, který je umělý a předkládaný jako nová estetická skutečnost k recepci divákovi, a mající jako hlavní cíl právě to, být nahlížen a analyzován jakožto nová estetická skutečnost. Takto ostatně Aristotelés prezentuje v Poetice mimésis, kterou nevnímá jen v literatuře či výtvarné tvorbě (s výtvarnem si Řekové pojem umění v dnešním smyslu nespojovali), ale také v hudbě, která napodobivý obraz tvoří jen výjimečně. Proto si myslím, že nadále nemůžeme hovořit $\mathrm{v}$ prrípadě divadla 
či jakékoli performance o vytrácení mimésis, nýbrž o vytrácení onoho ludického a naračního aspektu z ní. Protože právě absenci těchto aspektů nadále pozoruje a formuluje i sám Spitzbart, když ř́ká, že z divadla se vytrácí dialogičnost (narace) a „herci nemají co a o čem hrát,“ což vnímám jako vytrácení ludického aspektu tedy „hrajeme si na něco“.

Spitzbardt, následující Aristotela, spojuje dále mimésis s etikou. Nejvyšš forma zobrazování, kterou je pro Aristotela tragédie (možná i komedie, ale to nelze doložit spolehlivě), ${ }^{6}$ má člověka kultivovat. $\mathrm{Z}$ toho pro mě však vyplývá, že taková forma zobrazení má promlouvat o současných (či ne-časových) otázkách jazykem srozumitelným adresátovi. Raději bych se tedy neuchylovala, jak se to - snad mimoděk - Spitzbardtovi stalo, $\mathrm{k}$ adorování podob divadla bývalých věků nebo starších generací. Že se narace a ludus $\mathrm{v}$ dnešním divadle odehrávají někdy v jakési „nulové“ rovině - „hraji“ sám sebe, nepřevtěluji se, ukazuji originál, promlouvám, aniž bych zřetelně měnil identitu, - to může být přesným pojmenováním krize naší doby (nakolik jsou v našem světě př́tomny originály? Co nahrazujeme čím? Kam se originály ztratily?). Podobně jako fakt, že fragmentarizované vnímání není schopné (např. z důvodu ššrící se digitální demence či z jiných důvodů) sestavit příběh. Jinou otázkou může být absence či zhoubná role některých velkých př́iběhů $\mathrm{v}$ dějinách lidstva a jako reakce na to záměrné potlačování narace a její destrukce.

Ke Spitzbardtově kritice jsem ostražitá také proto, že nestanovuje jasná kritéria

6 Srov. např. dnes již příslovečné pokusy Richarda Janka zprostředkované textem Tractatus Coislinianus (JANKO 1987). Na základě těchto pokusů se rodí nové hypotézy i interpretace ztraceného/neexistujícího textu (WATSON 2012). pro to, co je pro něj „zdařilá“ mimésis a co ne: operuje pojmem postdramatické divadlo a vnímá je především jako synonymum pro neumětelství. Spojuje je s nevzdělaností, povrchností a degenerací komunikace, jež vedou $\mathrm{k}$ „neúctě $\mathrm{k}$ uměleckému originálu“ (36-37), podobně skeptický je k pojmu postmoderna (obojí jsou, přiznávám, termíny, kterým se sama raději vyhýbám pro jejich tekutost). Nalézá sice v této oblasti jednotlivé kvalitní výtvory, spojuje je však s genialitou a velkou naléhavostí. Obávám se jednak, že genialitu nelze nijak nárokovat v žádné oblasti lidské činnosti, ale také, a nemohu to nijak dokázat, že zde může jít spíše o problém krajový, a více než o rozkladu divadla bychom zde měli mluvit o možné degeneraci našeho divadelního školství (a snad nejlépe českého školství vůbec).

Jakkoli jsem ale ke Spitzbardtově kritice ostražitá, přiznávám, že mě taky nebaví chodit do divadla stále na totéž - tedy na to, co popisuje autor a co jsem se nyní snažila shrnout já. Na druhou stranu jsem ale také ochotna prripustit, že toto divadlo nevyjadřuje, nepopisuje, ani jinak nezasahuje můj životní pocit, je ale možná nějak svázáno s životním pocitem jiné komunity ve společnosti. Doufám v to, protože se zdráhám věrit tomu, že by vždy vznikalo nemotivovaně, jako nepovedený artefakt nebo z jakési vypočítavosti. Ostatně mi zde také samovolně vytanul další zádrhel nejen Spitzbardtova eseje: mechanicky aplikovat aristotelské vnímání umělecké mimésis na dnešní divadelní i společenskou situaci nelze už proto, že Aristotelés popisuje situaci jednotné a jasně vymezené komunity o několika stech tisících jedinců (patrně o velikosti krajského města), z níž jen vybraní jedinci (tedy pouze muži mezi ca 20.-60. rokem věku, kterých bylo jen max. 60 000) 
měli slyšitelný hlas, pokud šlo o vyslovování krisis, tedy soudu, zde soudu o umění. Takto jednolitá už společnost dávno není. Jen tak od oka soudím, že umění se mění v mnohohlas s koncem středověku, kdy vznikají stále rozmanitější komunity, které si začínají postupně osvojovat různé žánry a způsoby narace a zobrazování světa.

Wolfgang Spitzbardt akceptuje do jisté míry právě toto: že existují různé komunity konzumující různé divadlo, které on zřejmě a priorně hodnotí jako „lepší“ a „horší a liessmannovsky si zoufá nad nivelizací a znehodnocováním hodnot (59). Za viníka pak považuje kapitalismus, který globalizuje svět a zploštuje lidské vnímání. Zde si dovoluji upozornit na to, že již v Aristotelově době patřilo divadlo $\mathrm{k}$ druhům podnikání a bohatly z něj obce (ve smyslu establishmentu - ostatně jeho utužení divadlo také sloužilo) i herci a že již v Aristotelově době existovaly populární druhy divadla jako např. mímos, nehledě na to, že hlubokomyslné tragédie dochované do dneška jsou zřjmě výjimkami z pravidla. Ve 4. století, kdy psal Aristotelés, kvetly zápletky melodramatického rázu a největší úspěch mívaly často ty nejpitomější „slad'árny“ (a už Eurípidés ve 2. polovině 5. století býval na Velkých Dionýsiích často třetí, tedy propadl, a ani od Eurípida se nám nezachovaly jen samé nezpochybnitelné skvosty, drama Helena budiž jedním př́kladem za všechny).

Vratme se ale k Aristotelovi. Nevyvazuje mimésis z etických souvislostí, jak jsem již řekla. Na vrchol literární mimésis, kterou se v Poetice především zabývá, klade tragédii. Považuje ji za nejfilosofičtější poetický/literární druh, protože dokáže zobrazit svět nejkomplexněji, nejintenzivněji i nejjednotněji (zde si vypůjčuji estetické kategorie Tomáše Kulky: KULKA 2000:
200): tedy zobrazuje rysy a zákonitosti světa očištěné od nahodilostí a podružností (Aristotelovo chápání mimésis je tedy specifikací jeho teleologie na oblast umělecké tvorby). Aristotelés tuto dokonalost tragédie spatřuje i v tom, že se v ní poznání neomezuje jen na racionální kvality světa, ale že tragédie oslovuje stejně silně i lidské emoce, které také kultivuje (pojem očištění, katharsis, raději nechme pro jeho problematičnost stranou). Právě tato celistvost má být př́tomna i v divadle, po jakém touží Wolf Spitzbardt (63, bod 8). A z tohoto úhlu pohledu pak analyzuje divadlo různých moderních epoch, tedy divadlo starší než současné. Zvláštní pozornost přitom věnuje Brechtovi, Antoninu Artaudovi a Heineru Müllerovi. Analyzuje pojetí mimésis u těchto (i několika dalších) divadelníků jednak jako způsob, jak angažovat diváka na spatřovaném, což opatřuje termínem „adaptivní aspekt mimésis“, u Heinera Müllera a Brechta pak zdůrazňuje i využití mimésis $\mathrm{k}$ tomu, aby divák o spatřeném uvažoval a odhaloval „krizi okcidentu,“ včetně krize divadla.

Závěrem ještě upozorním na Spitzbardtův manifest ideálního divadla. Při jeho čtení jsem se usmívala: je to manifest divadla, které v mnoha ohledech tkví v minulosti, nebo je omezeno na některé divadelní druhy a nepostihuje rozmanitost divadelních projevů. Manifest totiž touží po divadle založeném na textu (Spitzbardtem také zmiňovaný mímos, herec dokonale plastický, ale spjatý historicky především s divadlem bez textové předlohy, by si tedy v tomto divadle neškrtl), divadle spravovaném dramaturgem, po divadle komorním (opera či taneční divadlo má tedy v tomto divadle fyzické blízkosti herce a diváka jen velmi omezené možnosti). Pro Spitzbardta je dokonalé 
divadlo takové, kde herecká mimésis rovná se ztotožnění se herce s rolí, kdy herci vkládají do role své vlastní pravdivé emoce. Otázka je, jak by v takovém divadle fungovala komedie, založená na distanci herce a role, na potlačení emočního prožitku jak u herce, tak u diváka, pochopitelně kromě poměrně mladého žánru tzv. romantických komedií.

V manifestu je dále přítomno mnoho utopií táhnoucích se až k ideálu hnutí Volksbühne a před něj do Athén (levné a dotované divadlo coby výchovná instituce, psychoterapie a sociální služba blahu obce), což je mnohokrát ztroskotavší sen všech divadelních reformátorů - a snad všech teatrologů včetně mě.

Je dále otázkou, zda pojmy, které s divadlem dle svého gusta spojuje, krása a smyslnost, nemohou být př́tomny i v jiných jeho podobách nežli v té, kterou vyznává Wolf Spitzbardt. Přitom krása již dávno není synonymem estetické hodnoty. Berme tedy recenzovaný text jako vyznání Wolfganga Spitzbardta divadlu, které má rád. Nevím, zda dnešní divadlo není schopné reflektovat příčiny společenské krize, jak se autor snaží dokázat a jak to explicitně ř́́ká na s. 60. Když ale sedím v divadle a pozoruji performanci, v níž mizí narace a ludus (nemůže však podle mě zmizet mimésis) a je pro mě tudíž emočně nedostupná a ve výsledku defektní, vzpomenu si vždy na citát ze Seneky, kterým Eva Stehlíková uvedla v jedné své knize kapitolu o římské imperiální tragédii: Talis hominibus fuit oratio, qualis vita. ${ }^{7}$ Zkrátka každá doba má své divadlo.

\section{Bibliografie}

CSAPO, Eric a Margaret MILLER (eds.). 2007. Origins of Theater in Ancient Greece and Beyond. Cambridge: Cambridge University Press, 2007.

JANKO, Richard. 1987. Aristotle: Poetics, with the Tractatus Coislinianus, reconstruction of Poetics II, and the fragments of the On Poets. Indianapolis: Hackett, 1987.

KNOX, Bernard. 1957. Oedipus at Thebes. New Haven: Yale University Press, 1957.

KULKA, Tomáš. 2000. Uměni a kýč. Brno: Torst, 2000.

STEHLÍKOVÁ, Eva. 2005. Divadlo za časů Nerona a Seneky. Praha: Divadelní ústav, 2005.

TAPLIN, Oliver. Proč byla maska pro řeckou tragédii rozhodující? Divadelni revue 31 (2020): 2: v tisku.

VERNANT, Jean-Pierre. 1992. Napětí a ambivalence v řecké tragédii. Svět a divadlo 3 (1992): 6: 27-38.

WATSON, Walter. 2012. The Lost Second Book of Poetics. Chicago/London: University of Chicago Press, 2012.

7 Překl.: „Řeč lidí byla taková, jaký byl jejich život" (STEHLÍKOVÁ 2005: 31). 